\title{
Arresting and Reversing Climate Change
}

\author{
S. L. Surana \\ Department of Electrical Engineering, Swami Keshvanand Institute of Technology, Management and \\ Gramothan, Jaipur-302017 (India) \\ Email: sls@skit.ac.in \\ Received 25.02.2021, received in revised form 09.03.2021, accepted 11.03.2021
}

\begin{abstract}
Increasing energy demands world over, depleting conventional fuel resources, rising in the level of atmospheric carbon dioxide, global warming and climate change are posing challenges to the existence of human population. These environmental concerns are forcing every nation to make their fossil fueled energy systems more efficient, reduce emissions of green house gases, conserve conventional fuels by making extensive use of renewable and other non-polluting energy resources. The existing power grid should be modernized by deploying smart devices, modern communication systems, fast computational techniques to reduce energy losses and incentivize generating companies to feed clean energy into the grid from nonpolluting and renewable sources of energy for sustainability and to reduce carbon emissions, which will not only arrest climate change but also reverse it which is very essential for the survival of human race.
\end{abstract}

Keywords- Climate Change, Paris accord, Renewable Energy Resources, Carbon Capture, Nuclear Power Energy, Efficiency, Energy Losses.

\section{INTRODUCTION}

Since independence India has progressed well in meeting the electricity demand of its citizens. Today it is the world's third largest power producer and third largest consumer of electricity. The Indian grid has an installed generating capacity of $377.261 \mathrm{GW}$ as on January 31, 2021 and out of which coal based power plants contribute $231.871 \mathrm{GW}$ which is $61.5 \%$ of total generating capacity. Burning of poor quality coal pollutes atmosphere and generates green house gases which contribute to global warming and climate change.

On February 7, 2021 a glacier broke off in Chamoli district of Uttrakhand causing massive damage. At least 170 people have been reported missing, 13.2 MW Rishiganga hydropower project near Joshimath was completely washed away, the 520 MW NTPC hydropower project on the Dhauliganga River was damaged badly and at least five bridges impacted by the floods cutting access to a number of villages. Geologists who have been studying the Himalayan glaciers said climate change is to blame.

\section{CLIMATE MITIGATION GOALS \& PARIS ACCORD}

At the beginning of the $19^{\text {th }}$ century before industrial revolution took place the global emissions of carbon dioxide from fossil fuel combustion was no more than 10 million metric tons a year which rose to 1.5 billion metric tons by 1950 and 6.5 billion metric tons by 2000 . In just one hundred years the emissions of carbon dioxide became 650 times due to combustion of fossil fuels. During the past millennium, the concentrations of $\mathrm{CO}_{2}$ remained fairly stable ranging from $275 \mathrm{ppm}$ in early 1600 to about $285 \mathrm{ppm}$ at the end of the $19^{\text {th }}$ century. Since then it started rising rapidly and became 415 ppm in May 2019.

The Paris agreement of 2015 was the first accord containing specific national commitments to reduce carbon emission in future. Having signed the Paris accord India is vigorously pursuing the policy of increasing the share of renewable energy mainly wind and solar to control $\mathrm{CO}_{2}$ emissions and arrest climate change. India has set a target of increasing the share of renewable energy to $175 \mathrm{GW}$ by 2022 which later on revised to $220 \mathrm{GW}$. It also intends to increase the share of electricity generation using renewable resources to $450 \mathrm{GW}$ by 2030 which will be $60 \%$ of total power generation. India has also committed to reduce emissions intensity per unit GDP by $33 \%$ to $35 \%$ below 2005 levels by 2030 .

According to the findings from a study done by Inter governmental panel for climate change, carbon emissions would rise to nearly 50\% above 2017 level, even if all the targets set under Paris accord were met by 2030 . The only way to keep the average world temperature rise to no more than $1.5^{\circ} \mathrm{C}$ by the end of the century would be to put emissions immediately into a decline mode and bring them to zero by 2050 . Even if the emissions are reduced by $50 \%$ by 2050 would limit the rise of global average temperature to $2{ }^{\circ} \mathrm{C}$. If the emissions are allowed to stay at the current rate, the average temperature rise at the end of the century would be $3^{\circ}$ or $4^{\circ} \mathrm{C}$ and would rise by $6^{\circ} \mathrm{C}$ if emissions increase at the current rate. This would render most part of the world including India uninhabitable, all the ice at the poles including Antarctica would melt and the sea level would rise by 60 metres. This would submerge all the coastal cities and islands of India and the world. To avoid such a catastrophic situation a range of different options that would limit the average temperature rise by $2^{\circ} \mathrm{C}$ and mitigate the climate change have been considered world over. These measures will be discussed in the subsequent sections. 


\section{GREATER FOCUS ON WIND \& SOLAR POWER GENERATION}

After signing Paris accord India will have to increase the share of renewable energy resources mainly wind and solar considerably. It has been forecasted that India will have to increase production of electrical energy by $60 \%$ upto 2040 in order to make India a manufacturing hub and self reliant nation. It is possible for India to achieve wind power target as it has a strong manufacturing base for the production of wind turbines with 20 manufacturers of 53 different wind turbine models of international quality upto $3 \mathrm{MW}$ in size. To achieve solar power target India has already set up 42 solar parks upto 2020. The largest among all the solar parks is located at Bhadla in Phalodi Tehsil (Jodhpur District). It is spread over 40 square kilometers with a total installed generating capacity of $2255 \mathrm{MW}$. A large number of such big projects are coming up in Madhya Pradesh at Neemuch, Shajapur, Chattarpur and Omkareshwar. Unfortunately, both wind and solar power plants suffer from the drawback that their generation is intermittent in nature and their capacity factor is very low compared to conventional sources of energy generation. Hybrid wind and solar plants to some extent can reduce the limitations of both and can provide much better generation profile as compared to stand alone wind or solar plants. Integration of wind and solar can be done either at the wind turbine level or PV array level or farm level using appropriate controllers.

\section{CARBON CAPTURE AND STORAGE (CCS)}

Thermal power plants, cement industries, iron and steel industries are some of the major industrial sources which discharge $\mathrm{CO}_{2}$ into the atmosphere and are responsible for global warming. Burning fossil fuels in thermal power plants alone produce $40 \%$ global emissions of $\mathrm{CO}_{2}$. In order to mitigate and reverse the climate change it is necessary to capture $\mathrm{CO}_{2}$ at the source and then in the compressed form transported to some suitable site for storage either in the ground, ocean or as a mineral carbonate. In the first option compacted $\mathrm{CO}_{2}$ is injected into deep geological formations such as depleted oil and gas reserves, deep saline aquifers and coal bed formations at depths below 800 to 1000 metres. The main problem of storing $\mathrm{CO}_{2}$ in deep geological formations is the possibility of its leakage into the atmosphere and thereby the damage it may cause. This technique which is called sequestration of $\mathrm{CO}_{2}$ from atmosphere is not picking up because there are no subsidies or incentive for the industries at present. Many countries also do not have suitable sites for storing $\mathrm{CO}_{2}$ underground. Although offshore capacity is available but it involves huge cost in transportation and injection of $\mathrm{CO}_{2}$ into the seabed.

\section{CARBON CAPTURE AND UTILIZATION (CCU)}

Recently carbon capture and utilization has attracted attention world over because in this technique $\mathrm{CO}_{2}$ emissions are captured at the source and converted into valuable products such as chemicals and fuels which can be sold. In one of the process the captured $\mathrm{CO}_{2}$ is made to react with metal oxides such as magnesium or calcium to form carbonates which can be used in construction of buildings. The captured $\mathrm{CO}_{2}$ can be utilized in the production of two commercially important chemicals urea and methanol. Unfortunately, the demand for these chemicals world over is not large enough to sequester significant amount of $\mathrm{CO}_{2}$ emissions to meet the carbon reduction targets. Moreover, conversion of $\mathrm{CO}_{2}$ to various chemical products is energy intensive owing to its thermodynamic stability and also require high selectivity catalysts. Also chemicals and fuels synthesized using captured $\mathrm{CO}_{2}$ have limited storage periods because of their short life span resulting in the release of gas back into atmosphere.

\section{CHALLENGES POSED BY INTERMITTENT SOURCES OF ENERGY}

The greater focus of the use of renewable energy sources mainly wind and solar for power generation during the last six years have led to their greater penetration in the Indian power grid. The low capacity factors for wind and solar arises from variable nature of these sources of energy. There is no energy generated when the wind does not blow or when the sun does not shine, and also when clouds pass over solar panels or during solar eclipse. Sudden fluctuation in the output of solar panels makes it difficult for the grid operator to balance generation and demand. Significant up or down ramps in solar power generation at the time of sun rise, sun set and rapid movement of clouds and in case of wind generation during wind storm can crash the grid due to imbalance between generation and demand.

Due to limited availability of hydro power resources and also due to several other problems associated with creation of new hydro power projects another good option for India is to go for nuclear power generation which does not contribute to green house gases.

\section{NUCLEAR POWER}

Both $\mathrm{CCS}$ and $\mathrm{CCU}$ techniques to capture $\mathrm{CO}_{2}$ are unsuitable for India due to lack of suitable sites for storing $\mathrm{CO}_{2}$ and require massive investment. In order to win the battle against climate change apart from expanding power generation using wind and solar India should greatly expand its power generation capacity using fission nuclear energy. As of January 31, 2021India has $6.78 \mathrm{GW}$ of installed power 
generation capacity which is just $1.8 \%$ of total installed generation capacity. Currently 22 pressurized heavy water reactors are in operation in seven nuclear power plants. India is in the process of launching its first prototype fast breeder reactor of 500 MW capacity near Chennai in Tamil Nadu. Unfortunately, India has very little reserve of uranium but fortunately it has world's largest reserve of thorium. Reactors based on thorium fuel cycle could satisfy all the India's energy needs for 400 years but this technology it not presently available. India has successfully implemented the first stage of three stage plan and now working for second stage before attempting the third stage. This process will take considerable time and therefore, some experts suggest that India should bypass the second stage of building fast reactors and go directly to third stage using molten salt breeder reactors (MSBPs) which will require less plutonium to convert the flect to a thorium fuel cycle. Small mass and compact form of the spent fuel in reactors along with zero emissions of green house gases are the most positive attributes of nuclear power compared to fossil fueled thermal power plants which generate enormous waste and release green house gases in the atmosphere.

The biggest hurdle in the expansion of nuclear power generation after Fukushima Daiichi nuclear disaster in Japan is to convince social activists and public about the safety of the people living around the plant and the disposal of radioactive waste generated from the reactors. The radioactive waste in the form of fission products generated in reactors working on thorium cycle would require only 300 years to decay to the levels of radioactivity provided by background rocks. Fortunately, India possesses the technology to store such radioactive waste safely for 300 years and therefore there is no danger to public life due to radioactive waste generated. To fulfill the commitments made at Paris meet India has plans to increase the nuclear power capacity to $63 \mathrm{GW}$ by 2032.

\section{IMPROVING ENERGY EFFICIENCY}

The aim of improving energy efficiency is to reduce energy consumption in manufacturing products and providing services to the users with same comfort. Improvements in energy efficiency are generally achieved by adopting a more efficient technology or production process so as to reduce losses. According to international Energy Agency improved energy efficiency in buildings, industrial processes and transportation could reduce the world's energy needs in 2050 by one third and help control emissions of green house gases.

Fossil fueled power plants which contribute a major share of electric power generation are only $30 \%$ efficient whereas in co-generation $90 \%$ of the fuel can be converted into usable energy. Similarly, energy intensive industries such as aluminium industry use a large amount of energy in resource extraction processes which can be considerably reduced by using more efficient processes.

In transport sector by introducing energy efficient vehicles considerable energy can be saved because they consume less fuel. This will also reduce emission of green house gases. It is claimed that these energy efficient-vehicles can reduce the fuel consumption by $50 \%$.

Street lighting consume considerable energy which can be reduced by $50 \%$ to $80 \%$ by using LED lamps and also by dimming lights during off-peak hours. India has robust energy efficiency programme under which more than 11 million LED street lights have been installed. The ministry of power and new \& renewable energy, Govt. of India in their report stated that various energy efficiency measures have led to electricity savings to the tune of 113.16 billion units during the year 2018-19 which is $9.39 \%$ of the net energy consumption. These efforts also resulted in the reduction of 151.74 million tons of $\mathrm{CO}_{2}$ emissions.

\section{REDUCTION IN ENERGY LOSSES IN THE GRID}

Energy losses both technical and commercial in our country are as high as $30 \%$ in some states. Attempts have been made in the past to reduce these losses but after an initial success these losses have started rising again. Distribution system is the weakest link of power system. The distribution sector needs to strengthen its network, adopt advance technologies of load forecasting, better planning and execution skills on an accelerated pace.

The use of d.c. has increased many fold due to large scale application of electronic devices. In business electronics, data servers, variable frequency drives in industries require tremendous amount of energy conversion from A.C. to D.C. Today nearly $30 \%$ of power generated pass through power electronics converters before it is utilized. It may go even up to $80 \%$ in near future due to solar and wind power generation. These frequent conversions from A.C. to D.C. and back involve losses and bring inefficiency. Energy losses due to all these conversions can be avoided by developing hybrid AC/DC infrastructure and operations.

\section{CONCLUSION}

India is determined to provide access of uninterrupted quality power supply in a sustainable manner and at the same time make efforts to mitigate and reverse the climate change. After Paris accord on climate change there is no option but to increase the share of renewable energy resources considerably. In order to meet this challenge with constrained emission of greenhouse gases India will have to adopt a policy to generate electricity using a combination of 
dispatchable and variable generation, centralized and distributed generation for several decades using resources which do not contribute to green house gases. In order to offset the effect of variable nature of energy output from wind and solar energy power plants, it is necessary to initiate steps urgently to develop emission free nuclear power technology based on thorium fuel cycle, expand nuclear power generation using thermal and fast breeder reactors and develop effective energy storage devices. Smart inverters suitable for roof top solar PV systems with fault ride through capability and virtual control inverters need to be developed and installed with solar systems to improve continuing of power supply and to reduce cascade tripping. It is also necessary to strengthen the existing transmission network by adding transmission capacity of more than $100 \mathrm{GW}$ to connect renewable energy rich locations such as Rajasthan for solar energy and Tamil Nadu for wind energy with demand centres. In order to meet the commitments made at the Paris meet India will have to focus on energy efficiency in a big way so that energy consumption can be reduced. Replace all existing incandescent lamps by more efficient LED lamps in street lighting; scrap all inefficient vehicles which are older than twenty years by energy efficient vehicles or by electric vehicles which do not pollute the environment. Create nationwide infrastructure for recharging of these electric vehicles, reduce technical and commercial losses in the grid, install hybrid A.C/D.C grid to reduce conversion losses.

Reversing climate change requires extraction of $\mathrm{CO}_{2}$ from atmosphere. Carbon capture and storage (CCS) technique for reversing climate change is not appropriate for India as it has no suitable geological storage capacity. Carbon capture and utilization (CCU) technique is energy intensive and can reduce $\mathrm{CO}_{2}$ only by a small fraction that is about $0.5 \%$ to $1.0 \%$. Tree plantation is a better choice to extract $\mathrm{CO}_{2}$ from atmosphere. In the presence of sun light plants have the natural ability to convert $\mathrm{CO}_{2}$ drawn from the atmosphere with water extracted from the soil into liquid and solid organic compounds. Farmers in India, as a practice burn the farm waste and pollute the atmosphere. If this farm waste after every crop is converted into biochar by the process of supertorrefaction and burried in the farm lands will not only increase the farm productivity but will also help in reducing the level of $\mathrm{CO}_{2}$ in the atmosphere. It is claimed that about 100 billion tonnes of biochar is manufactured from the global annual farm waste and burried in the farm lands can lower atmosphere $\mathrm{CO}_{2}$ by $100 \mathrm{ppm}$. Burring of biochar into the farm land will increase soil carbon below ground and increase growth of crops above ground and effectively remove $\mathrm{CO}_{2}$ from atmosphere, and help in reversing the climate change with much lower investment.

\section{REFERENCES}

[1] Adoption of Paris agreement, United Nation Framework convention on Climate Change Document No., FCCC Framework convention on Climate Change Document No. FCCC/2015/L.9 dated 12.12.2015.

[2] Rosa M. Cuellar-France. Adisa Azapagic, 'Carbon Capture, Storage and Utilization technologies; A critical analysis and comparison of their life cycle environmental impacts', Journal of CO2 Utilization 9(2015) P82-102.

[3] Frank H.Shu, 'Stopping and Reversing Climate Change', Part I and II Resonance, January 2019 P.51-71 \& February 2019, P.181-199.

[4] Jacopo Buongiorno et at, 'Nuclear Energy in a Carbon Constrained World, IEEE Power \& Energy Magazine Vol. 17 No. 2, March/April 2019 P. 16-24

[5] Amber Mahone et at, "On the Path to Decarbonization", IEEE Power \& Energy Magazine, Vol. 15, No. 6 Nov/Dec. 2017 P 61-69.

[6] Energy Efficiency Indicators 2020, International Energy Agency, June 2020.

[7] Government of India, Power sector at a Glance All India. 